\title{
Implementation Analysis of Early Detection and Intervention Program for Growth and Development of Children Under Five at Tegal Health Centers
}

\author{
Adrestia Rifki Naharani 1), Hermanu Joebagio's), Adi Prayitno ${ }^{3)}$ \\ 1) Masters Program in Public Health, Sebelas Maret University, Surakarta \\ 2) Faculty of Teaching and Educational Sciences, Sebelas Maret University, Surakarta \\ 3) Faculty of Medicine, Sebelas Maret, Surakarta
}

\begin{abstract}
Background: The first five years of life is often considered as golden period, critical period, or window opportunity. During this period there is maximal growth and development. Early Detection and Intervention Program for Growth and Development of Children Under Five (SDIDTK) is a program that aims to do early detection and intervention when there is an impairment in growth and development in children under five or pre-school children. Early detection allows early intervention. This study aimed to analyze the implementation of early detection and intervention program for growth and development of children under five.

Subjects and Method: This was a qualitative study with case study approach, conducted in Tegal Health Centers, Tegal, Central Java. Nineteen key informants were selected purposely for this study, including health center midwife, midwife who were in charge of coordinating child and adolescents affair, head of the health center, head of Children and Adolescents Division at District Health Office Tegal, and mothers who had children with growth disorder.

Results: SDIDTK has been implemented since 2010. The communication aspect has not been implemented consistently. There was a lack in resources, including personnel, equipment, and infrastructure. The attitude of the program implementer was not positive, because they considered that program was not effective. Guideline book and Standard Operating Procedure (SOP) were available. Growth examination activities were sufficient, but development examination activities were lacking. The reporting system was not sufficiently implemented.

Conclusion: SDIDTK program was not been implemented optimally in Tegal. It is sugested to enhance the motivation of the program implementer and improve the equipment and they infrustructure for SDIDTK implementation.
\end{abstract}

Keywords: implementation, SDIDTK program, growth, development, children under five

\section{Correspondence:}

Adrestia Rifki Naharani. Masters Program in Public Health Sebelas Maret University, Surakarta

\section{BACKGROUND}

A child is a yearning of every family. In addition, every family also expects for their children to optimally grow and develop (physically, mentally or cognitively, and socially healthy), can be proud of, and also beneficial for the nation, children should obtain attention since they were still in the womb up to they become grown up (Soetjiningsih, 2012).

Based on the report of Health Ministry of Republic of Indonesia on the coverage of healthcare service for children under fivein the growth detection the number of toddlers who endure growth and development impairment in Indonesia is 45.7\% (Kementerian Kesehatan RI, 2010). Early detection for growth and development is an activity or examination to early find the occurrence of growth and developmental delay. By early finding the deviation or problem on children growth and development, then an intervention will be easier 
to conduct for growth and development impairment of children under five.

In the effort to fulfill the children's right, the attention toward Early Age Children becomes important since it is a Golden Period, window of opportunity, and also critical period. It means that the brain plasticity of a child in this age possess both negative and positive sides. The brain positive side in this age is more open for learning and enrichment process, however the negative side is more sensitive toward unsupportive environment such as inadequate nutrient intake, less of stimulation, and do not get adequate healthcare service.

Health effort which is conducted since the pregnancy up to the first five years of their life, aims to maintain the life sustainability as well as to improve the children quality of life to attain optimal growth of physic, mental, emotional and social also possess multiple intelligence in accordance with their genetic potential (Kementrian Kesehatan RI, 2010).

There are numerous that influence children growth and development. There are also some factors that influence, such as internal and external factor. Internal factor includes race/ethnicity or nationality, family, age, sex types, genetic, and chromosome abnormality, whereas external factors include prenatal factors (nutrition, mechanical, toxic or chemical, endocrine, radiation, infection, immunology abnormality, anoxic embryo or placenta function disorder that causes growth impairment, and maternal psychology) delivery factor, post delivery factor (nutrition, chronic diseases, physical environment, psychology, endocrine, socioeconomic, nurture environment, stimulation and medication). There are numerous problems occur during child growth and development including physical growth, motor, language, emotion, and behavioral development (Kementrian Sosial, 2014)

Especially for physical growth impairment, that consists of child growth beyond normal and child growth impairment below normal, the growth monitoring can be carried out by using Growth Chart (KMS) which is easy to conduct by mothers to know child growth. Meanwhile for development consists of gross motor, fine motor, language as well as socialization with the environment.

Early detection for growth and development is an activity or examination to early discover growth and development problems or deviation (Dewi, 2010).

Early Detection and Intervention Program for Growth and Development (SDIDTK) service is very important because the growth and development abnormality which is early detected will get the appropriate intervention. Growth and development which is to late to get discovered may lead to children development drawback and less effective therapy (Kementerian Kesehatan RI, 2010).

SDIDTK program is one of the primary tasks of Community Health Center. The activity is comprehensively and coordinately conducted in a form of partnership among family (parents, nanny, and other members of the family), society (cadres, professional organization, civil society Organization) with professional personnel.

Government has made some efforts in supporting the implementation of SDIDTK. One of the government programs is by publishing the Manual for the Implementation of SDIDTK in Primary Care Service.

Community Healthcare Center and it network as primary healthcare service organization is at the front line holding an important role in attaining the purpose and the accomplishment of SDIDTK program. The caretaker of SDIDTK program is 
responsible to manage the program and attain the purpose of the program in Community Health Center. In implementing the duty, program caretaker should apply management functions, such as organizing and actuating function.

The data obtained from Tegal Regency Health Office shows that SDIDTK coverage in 2014 for the existing Community Health Center is not clearly visible whether it belongs to the coverage of SDIDTK program implementation since the coverage included within visits made by midwives to newborns up to under five years old children so it can not illustrate the coverage of real SDIDTK examination. Since it is assumed that when midwives conduct visits to infants and children under five year old, it is already considered as SDIDTK examination.

The other data also only show the data on growth impairment, however it does not show the data for developmental impairment. Whereas Tegal Regency has 29 Community Healthcare Center which have implemented SDIDTK program. However it can not be confirmed whether SDIDTK examination includes only growth or has already included development examination.

The purpose of then study is to analyze the implementation of Early Detection and Intervention Program for Growth and Development of children under five years old in Integrated Healthcare Post of Tegal Regency.

\section{SUBJECTS AND METHOD}

The study was qualitative study with case study approach. Data collection was conducted with in depth interview, observation and document study. Informant in the study consists of 19 people, namely midwives of Community Health Center, Head of Children and Adolescent Division of Tegal Health Office, Head of the Com- munity Health Center, Coordinator Midwife of Children and Adolescent of Community Health Center and mothers who have child under five years old with growth impairment.

\section{RESULT}

\section{Argumentation of the Study}

From an interview with the Head of Children and Adolescent Division of Tegal Regency Health Office, it was discovered that SDIDTK program has been implemented in Tegal Regency since 2010. SDIDTK program is national program for children welfare. The program is considered beneficial for early examination on the deviation in growth and development.

The purpose of SDIDTK program is to make all children under five years old may optimally grow and develop, if they are detected to suffer from impairment in growth and development then it is expected to have intervention which is appropriate with the problems.

The target of SDIDTK program is all toddlers of 0-5 years old and also preschool children of 5-6 years. SDIDTK examination is conducted within a certain period of time.

\section{Communication}

The form of communication conducted in SDIDTK program is through training nad socialization. The Head of Children and Adolescent Division of Tegal regency Health Office joining SDIDTK training which was conducted in Provincial level. Afterward Coordinator Midwife of Children and Adolescent of Tegal Regency Health Office organized SDID training for coordinator midwives of children and adolescent of Community Healthcare Center level, and then coordinator midwives of children and adolescent of Community Healthcare Center forwarded the result of SDIDTK training by organizing socialization to 
Indonesian Journal of Medicine (2016), 1(3): 175-182

https://doi.org/10.26911/theijmed.2016.01.03.05

midwives of Community Healthcare Centers who later became the executors of SDIDTK program.

For the clarity of the information during training and socialization about targets and also purpose of SDIDTK program, Head of Children and Adolescent Division of Tegal Regency Health Office had given explanation as clearly as possible on purpose of the program, targets and also the method of SDIDTK examination. The information clarity was also experienced by Head of Children and Adolescent Division of Community Healthcere Center as well as midwives of Community Healthcare Centers. SDIDTK socialization by coordinator midwife of children and adolescent of Community Healthcare Center to midwife of Community Healthcare Center as the executor was not conducted regularly instead.

During socialization process of SDIDTK program it was considered insufficient since it was not regularly implemented. And also the coordinator midwife of children and adolescent of community healthcare center had been substituted, it became a problem also since the programmer is new, they did not yet join the training form Health Office. Finally they did not conduct socialization to midwives of community healthcare centers as the executors since they did not really understand the program. Meanwhile Health Office does not regularly organize SDIDTK training every year and the training target is also on alternate instead. It turned to be an obstacle for SDIDTK program implementtation in Tegal Regency.

\section{Resources}

The study obtained a result that the executors of SDIDTK program had joined the training or socialization before. Not all of Coordinator Midwives of Children and Adolescent of Community Health Centers have joined the training, since some of them were new in the position, the training was attended by the previous Coordinator Midwives of Children and Adolescent. However they had got socialization about SDIDTK program by the previous Coordinator Midwife of Children and adolescent.

The implementation of SDIDTK program in Tegal regency was still lack of infrastructures. The equipment provided was only for measuring the growth whereas for developmental examination the equipment needed was not available. Developmental examination needed forms contains developmental points which fit with the age should be examined by the healthcare officers. However because it was not available it only used growth chart and only asked the parents who accompanied. In developmental examination also greatly needed educational playthings used to evaluate whether toddlers have reach the developmental stages that fit their age or not. If not then it needs to give stimulation to the toddlers to attain the developmental stages.

For Health Office of Tegal Regency, programmer of children and adolescent had allocated fund from Regional Budget II for SDIDTK program which was planned to have SDIDTK training and also the procurement of educational playthings for every community healthcare center. However not all of the community healthcare centers had the budget to implement the program. So that examination forms were not available neither examination equipments were still inadequate.

\section{Disposition/Attitude of the Executors}

From the interview result toward midwives as informant it was discovered that all midwives stated that SDIDTK program was quite good to be implemented however it was considered to be less effective since the 
examination of only one toddler had taken much time if it should examine in accordance to the format and available manual. There should be a special time to implement it.

All midwives as informants believed that the program may help the examination of growth and development on toddlers since by doing SDIDTK examination it would rapidly early detect the impairment either in growth or development of the toddler so that it would be able to give appropriate intervention in order to overcome the impairment.

The result of in-depth interview to midwives as informant about the conformity of the SDIDTK program implementation with the existing manual discovered that all midwives stated that the implementation was not yet maximally suitable with the manual available, because of the inadequacy of infrastructure, fund, time and also labor and so it was not yet maximally implemented. The implementation was conducted in accordance with the capability of each midwife when they implemented the program in Integrated Healthcare Post.

\section{Bureaucracy}

Based on the result of the interview with Head of Children and Adolescent Division of Tegal Regency Health Office it was discovered that SDIDTK program already had the manual that was SDIDTK Instruments. The manual was also distributed to coordinator midwife of children and adolescent of Community Healthcare Center during training and each executor midwife should also have the manual.

There was an SOP on the implementation of SDIDTK program. The SOP was included within the manual book of SDIDTK implementation. Collaboration in cross sectors level was considered insufficient. Although there was community healthcare center that already organized training for pre-school teachers in which it was aiming at the teachers to help in the implementation of SDIDTK examination for their toddler students at every month. Subsequently the result of the examination will be reported to village midwives or community healthcare center. However up to currently it was not yet implemented.

\section{SDIDTK Implementation}

The implementation of growth examination was conducted every month in Integrated Healthcare Post. The examination conducted included examination on body weight, body height, and also head circumference. The equipments used also had been completed namely body scale, consisted of steelyard, bathroom scale, baby weight scale. There were body height scales, and metline to measure head circumference.

Developmental examination was conducted every month in Integrated Healthcare Post to toddlers who were within the range of developmental examination. However not all midwives conducted the examination. The implementation of developmental examination was not conducted by using SDIDTK format instead only used growth chart and asked the parents or anyone who accompanied the toddlers to Integrated Healthcare Post. The equipment used was only what available there, since the educational playthings were not available for developmental examination. If there was a toddler who endured developmental impairment, then they would teach the parents to give stimulation. If it was necessary it would be consulted to midwife of children and adolescent division. If the condition of the toddler needed further referral then it would be referred to hospital or pediatrician.

SDIDTK reporting was conducted every month. Midwife of community healthcare center submitted the report to coordinator midwife of children and 
adolescent of Community Healthcare Center. And then coordinator midwife of children and adolescent of Community Healthcare Center would report the result of implementation of SDIDTK examination in Integrated Healthcare Post to Head of Children and Adolescent Division of Tegal Regency Health Office

SDIDTK program implementation in Tegal regency did not have a particular reporting format yet. Executor midwife only reported the result of growth examination. There was no reporting for development. If there was a report it only followed the number of unspecific growth report or only wrote the result as "NIL" for growth impairment or "Normal" for all toddlers. it definitely influenced the quality of the next reporting by coordinator midwife of children and adolescent of Community Healthcare Center to Head of Children and Adolescent Division of Tegal Regency Health Office since the reporting given was not accurate. So that later the coverage for SDIDTK could not represent the implementation of conducted activity.

\section{Obstacle Factors}

The obstacles definitely affected the implementation of SDIDTK program which was less maximal so that it needed the effort from various parties to be able to minimize the obstacles. The obstacles among others were:

1. Insufficient socialization or refreshing which was conducted so that sometimes the executor midwives forgot.

2. So many SDIDTK instruments which should be used in the examination so that executor midwives became reluctant to examine using SDIDTK format.

3. There was no infrastructure which was adequate in SDIDTK examination that were examination format and educational playthings used in the developmental examination
4. The budget was not maximal yet for the implementation of the program so that it was not sufficient for the procurement of examination format and also educational playthings.

5. The executors were village midwives who were also already had quite duty and responsibility, not only doing SDIDTK examination.

From the elaboration above it can be concluded that:

1. SDIDTK program in Tegal Regency has been conducted since 2010. The program aimed to be able to early detect the growth and development impairment on toddlers so that it could conduct early intervention which was appropriate for the toddler.

2. Communication within SDIDTK program implementation in Tegal Regency was still insufficient since the training and socialization on SDIDTK program were not conducted regularly each year.

3. Resources within SDIDTK program implementation from the personnel side was quite good, since they were all trained and joined the socialization on SDIDTK program. However there was no regular activity that might increase their competency in implementing SDIDTK examination. From the side of equipment and infrastructure were still very inadequate since there was no examination format provided for SDIDTK examination neither educational play things used in development examination.

4. The commitment of executors in implementing SDIDTK program was quite positive, although the implementtation was not yet in accordance with manual book and considered less effective for the time and labor constraint, however executor midwives was still confident 
that the program could be beneficial for the growth and development of toddlers.

5. Bureaucracy applied in implementing SDIDTK program implementation was good since it has equipped with SOP to SDIDTK program implementation in Tegal Regency both in Health Office and Community Healthcare Center.

6. SDIDTK program implementation in Tegal regency was not yet optimal since it only applied growth examination, for development examination was not yet applied well as the manual of SDIDTK. The reporting of SDIDTK program was not optimal also since the reporting occurred was only the result of growth examination.

7. The obstacle factors for SDIDTK program implementation in Tegal Regency were inadequate infrastructure, SDIDTK examination time and also the executors to conduct SDIDTK examination

\begin{tabular}{l}
\hline REFERENCE \\
\hline Chamidah AN (2009). Deteksi Dini Gang- \\
guan Pertumbuhan dan Perkembang- \\
an Anak. Jurnal Pendidikan Khusus \\
(5).
\end{tabular}

Denzin, Norman K, Lincoln, Yvonna S (2010). Qualitatvie Research. Pustaka pelajar.

Dinas Kesehatan Kabupaten Tegal (2014). Profil Kesehatan Tahun 2014. (2015). Profil Kesehatan Kabupaten Tegal Tahun 2015. (2015). Data Cakupan SDIDTK Tahun 2014.

Puskesmas Tarub (2015). Profil Puskesmas Tarub 2015. Tegal.

Puskesmas Slawi (2014). Profil Puskesmas Slawi 2014.

Puskesmas Kalibakung (2014), Profil Puskesmas Kalibakung 2015.

Feti KD (2014). Efektifitas SDIDTK terhadap peningkatan angka Penemuan
Dini gangguan Tumbuh kembang pada Balita di Posyandu Teluk Wilayah Puskesmas Purwokerto Selatan.

Irmawati (2008). Analisis Hubungan Fungsi Manajemen Pelaksanaan Kegiatan Stimulasi Deteksi dan Intervensi Dini Tumbuh kembang (SDIDTK) Dengan Cakupan SDIDTK Balita dan Anak Prasekolah di Puskesmas Kota Semarang Tahun 2007. Universitas Diponegoro Semarang.

Kementrian Sosial Republik Indonesia (2014). Seribu Hari Pertama Kehidupan: Kemensos RI.

Kementrian Kesehatan Republik Indonesia (2010). Pedoman Pelaksanaan Stimulasi Deteksi dan Intervensi Dini Tumbuh Kembang Balita: Kemensos RI.

Kusminarti (2009). Faktor-faktor yang berhubungan dengan pertumbuhan balita usia 2-4 tahun di kelurahan salaman mloyo kecamatan semarang barat kota semarang tahun 2009.

Lismadiana (2014). Pertumbuhan. www. uny.ac.id/sites/default/files/ perkembangan.pdf diakses bulan Juli 2016

Mangkunegara, Anwar P (2005). Evaluasi Kinerja SDM. Bandung: Refika Aditama.

Maritalia D (2009). Analisis Pelaksanaan program Stimulasi Deteksi dan Intervensi Dini Tumbuh Kembang (SDI DTK) dan Anak PraSekolah di Puskesmas Kota Semarang Tahun 2009. Universitas Diponegoro.

Maryunani A (2012). Ilmu Kesehatan Anak dalam Kebidanan. Jakarta: CV TIM.

Mathis RL, Jackson JH (2002). Manajemen Sumber Daya Manusia, Jakarta: Salemba Empat.

Moleong LJ (2013). Metodologi Penelitian Kualitatif (EdisiRevisi ). Rosda.

Muslimah (2013). Analisis Perbedaan Kinerja Bidan Desa yang Sudah dan Belum di Latih Manajemen Terpadu Ba- 
Indonesian Journal of Medicine (2016), 1(3): 175-182

https://doi.org/10.26911/theijmed.2016.01.03.05

yi Muda dalam Penatalaksanaan Kunjungan Neonatal di Kabupaten Kudus Tahun 2011. Semarang: Fakultas Kesehatan Masyarakat. UNDIP.

Palasari V (2012). Keterampilan Ibu Dalam Deteksi Dini Tumbuh Kembang Terhadap Tumbuh Kembang Bayi. Jurnal STIKES 5 (1).

Patton MQ (2009). Metode Penelitian Kualitatif. Pustaka Pelajar.

Rachmat PS (2009). Penelitian Kualitatif. Equilibrium 5 (9).

Rahayu S (2013). Pertumbuhan dan Perkembangan Balita Di Posyandu Surakarta. Kementrian Kesehatan Politeknik Kesehatan Surakarta.

Sari DA (2014). Desain Penelitian Kualitatif. Eureka Pendidikan. http://www. eurekapendidikan.com/2014/11/desai n-penelitian-kualitatif.html diakses tanggal 10 Januari 2014.

Soetjiningsih (2014). Tumbuh Kembang Anak. Jakarta: EGC.
Sulaeman ES (2015). Metode Penelitian Kualitatif \& Campuran dalam Kesehatan Masyarakat. Surakarta: UNS Press.

Wahyuni A (2014). Dampak Program Bina Balita (BKB) Terhadap Tumbuh Kembang Anak Balita 6-24 Bulan. Jurnal Pustaka Kesehatan 2(1).

Wuridiyah (2014). Komunikasi dan Kejelasan Informasi https://mukhtaralim. wordpress.com/2014/12/19/komunik asi-dan-kejelasan-informasi/ diakses bulan Juli 2016.

Yulianto S (2010). Hubungan Fungsi Pengorganisasian dan penggerakan Terhadap Cakupan Stimulasi Deteksi Dan Intervensi Dini Tumbuh kembang (SDIDTK) Balita dan Anak Prasekolah di Kabupaten Bangkalan tahun 2010. UNS Solo. 